\title{
PROČ BY MĚL POVALEČE LEOPOLDA HILSNERA ZNÁT KAŽDÝ PRÁVNÍK?
}

\author{
MICHAL URBAN, ELIŠKA HRONOVÁ*
}

\begin{abstract}
Why Should Every Lawyer Know Idler Leopold Hilsner?
This article concentrates on the case of Leopold Hilsner, a young Jew who was in 1899 accused and most probably unjustly sentenced to death for a ritual murder of a nineteen-year old woman Anežka Hrůzová, whose body was found a few days before Easter. The first part of the article sums up the historical facts about the Hilsner Case and emphasises the antiSemitic atmosphere in the society at the end of 19th century. This atmosphere intensively contributed to a conviction of Leopold Hilsner for an alleged ritual murder. The authors discuss several characteristics of the proceeding which had in their view an impact on the progress and the final judgment of the trial. They describe the relationship between a client and an attorney and stress the role of Hilsner defence lawyer, dr. Auředníček. Furthermore, they debate particularities of a jury trial, which was brought in the Hilsner Case, and describe personal engagement of Tomáš Garrique Masaryk, professor of Charles University in Prague and later president of Czechoslovakia, in the case. In conclusion, the authors stress that the Hilsner Case and its message are too important to be forgotten.
\end{abstract}

Keywords: Leopold Hilsner; T. G. Masaryk; hatred; ritual murder; trial

Klíčová slova: Hilsner; T. G. Masaryk; nenávist; rituální vražda; soudní proces

DOI: $10.14712 / 23366478.2019 .22$

V březnu 2015 navštívili dva muži Polnou, malou obec na hranici mezi Čechy a Moravou. Prohlédli si hrob mladé dívky a na místě, kde před více než sto lety přišla násilně o život, připevnili ceduli s její podobiznou a nedlouhým textem. Soud následně jednoho $\mathrm{z}$ nich za tento čin odsoudil $\mathrm{k}$ jednoletému trestu odnětí svobody.

Nejednalo se totiž o obyčejné turisty a ani cíl svého výletu nezvolili náhodně. Jihlavský soud potrestal podmíněným trestem nechvalně známého představitele krajně pravicové Národní demokracie a autora seznamů pravdoláskařů a židů, Adama B. Bartoše. Doprovázel ho spolustraník Ladislav Zemánek, který zejména kvůli projevené

* JUDr. Mgr. Michal Urban, Ph.D., je odborným asistentem na Právnické fakultě UK na katedře politologie a sociologie, Mgr. Eliška Hronová působí na Ministerstvu spravedlnosti v Kanceláři vládního zmocněnce pro zastupování České republiky před Evropským soudem pro lidská práva, je absolventkou Právnické fakulty UK. 
lítosti nakonec od soudu odešel bez trestu. Proč cestovali právě do Polné? Svoji averzi k židům chtěli propojit s více než sto let starou událostí, kterou česká historie označuje prostým slovem „hilsneriáda“. Na jejím počátku došlo k vraždě dívky nedaleko Polné. „Její smrt český národ semkla,“ napsali na své ceduli, „a s naléhavostí mu ukázala nutnost řě̌ení židovské otázky. Židovská otázka nebyla dosud uspokojivě vyřešena."1 Hilsneriáda nepředstavuje přitom jen jednu z povinných kapitol středoškolského dějepisu. Jde o zásadní soudní případ, který coby lupa ukazuje českou společnost na samém přelomu 19. a 20. století. Proč dnes ještě stojí někomu za to se $\mathrm{k}$ tomuto starému př́ípadu vracet?

\section{JAK HILSNER DO POTÍŽÍ PŘIŠEL}

Vše začalo vraždou. Tělo se našlo 1. dubna 1899 poblíž obce Polná a brzy zjistili, že se jedná o devatenáctiletou švadlenu Anežku Hrůzovou. ${ }^{2}$ Dívka byla nalezena polonahá mezi stromky v lese nedaleko cesty. Ležela na břiše s koleny ohnutými nahoru, přikrytá několika větvemi. ${ }^{3} \mathrm{Na}$ krku měla velkou řeznou ránu. Vysvlečené a roztrhané kusy jejího oděvu naznačovaly, že motiv vraždy byl dost možná sexuálního charakteru. Řeznou ránu na krku a absenci většího množství krve na místě, kde byla nalezena, si občané z přilehlých obcí velmi rychle dokázali vysvětlit: muselo dojít $\mathrm{k}$ takzvanému podkošerování, tj. rituální vraždě, které se měli dle prastaré, ještě středověké pověry dopouštět židé, nebot' prý potřebovali krev křest’anských panen do velikonočních macesů. Mrtvé tělo přitom místní shodou okolností objevili právě na Bílou sobotu.

Anežka Hrůzová se ztratila tři dny předtím, když se vracela domů z nedaleké Polné, kde se učila švadlenou. ${ }^{4}$ Při vyšetřování její vraždy se postupně vynořilo více vyšetřovacích verzí. $Z$ výpovědí sousedů vyplývalo, že vztahy v Anežčině rodině byly poměrně napjaté, často u nich doma docházelo $\mathrm{k}$ nejrůznějším hádkám. Verzi, že by za její vraždou mohl stát bratr Jan či její matka Marie, nasvědčovalo, že ji oba začali postrádat až dva dny poté, co se ze služby v Polné nevrátila domů. Jako možný podezřelý byl dále označen neznámý muž ve věku 20-30 let, střední postavy, v popelavě šedých šatech, který se onoho osudného dne pohyboval v okolí lesa, $v$ němž bylo nalezeno tělo dívky. Jeho spojitost s vyšetřovaným zločinem dokládala výpověd' jedné ze svědkyň, která ho potkala a při vyšetřování vypověděla, že měl v ruce bílou dřevěnou hůl, jež byla následně nalezena pobliž Anežčina těla. Možným podezřelým měl být i nádeník František Pytlík, který se v době Anežčiny vraždy pohyboval ve stejném lese a při vyšetřování byly na jeho šatech nalezeny krvavé skvrny. ${ }^{5}$

\footnotetext{
1 Policie za pomoci odborníka na extremismus dospěla k závěru, že jde o podněcování nenávisti vůči židům, nebot' sousloví „,konečné řešení židovské otázky“ používali nacisté především v souvislosti s židovským holokaustem. Srov. https://www.irozhlas.cz/zpravy-domov/za-protizidovsky-text-rocni-podminka-soud -potvrdil-trest-pro-predsedu-narodni-demokracie-bartose_201703071113_dpihova.

KOVTUN, J. Tajuplná vražda: Připad Leopolda Hilsnerā. Praha: Sefer, 1994, s. 29.

Tamtéž, s. 12.

Tamtéž, s. 11, 16.

Tamtéž, s. 31-37.
} 
Přesto byly všechny tyto verze rychle opouštěny a hlavní pozornost nejen místních, ale i vyšetřovatelů se upnula na Leopolda Hilsnera, nepř́liš inteligentního, obecně nesympatického a důvěru nevzbuzujícího 22letého židovského nedoučeného obuvníka, jenž byl toho času nezaměstnaný a často se pohyboval mezi povaleči a tuláky. ${ }^{6}$ Jeho hlavní vina, jak se postupně ukazovalo, spočívala $\mathrm{v}$ tom, že byl žid, a mohl proto být podezrríván z podkošerování. Vyšetřovatelé se na něj zprvu zaměřili pouze na základě ničím nepodložených dohadů. Leopold Hilsner se však při vyšetřování a soudním procesu v Kutné Hoře dopouštěl ze strachu drobných lží a nepřesností, které sice vůbec nic nedokazovaly, avšak posilovaly domněnku, že lže, protože je skutečným vrahem. Nemalou měrou k jeho obvinění přispěla rovněž nekvalitně vyhotovená pitevní zpráva, kterou polenští lékaři Michálek a Prokeš nezpracovali celou v den nalezení dívčina těla, ale až s několikadenním odstupem. Ve zprávě se lékaři nijak nevěnovali otázce, kolik krve dívka ztratila, ani se nevyjádřili k významu strangulační rýhy, kterou dívka utrpěla zřejmě po škrcení, či k ránám na hlavě. Za smrtelné poranění označili bez většího rozvedení řeznou ránu na krku, z čehož si bylo snadné vyvozovat, že dívka zemřela rychlým vykrvácením. ${ }^{7}$ Ačkoli později byly zavádějící závěry uvedené v této zprávě vyvráceny a bylo prokázáno, že Anežka Hrůzová zemřela zardoušením, veřejnost zůstala o správnosti této zprávy a spáchané rituální vraždě i nadále přesvědčena.

O Hilsnerově vině nesvědčily žádné přímé důkazy. Na předpokládaný čas vraždy neměl sice alibi, avšak to by k podání obžaloby samo o sobě nikdy nestačilo. Byl vzat do vazby a během vyšetřování se, a to i s několikaměsíčním odstupem, postupně začínali hlásit další svědci, kteří si zpětně vybavovali události z vražedného dne a vesměs svědčili v Hilsnerův neprospěch.

Vyšetřováním př́padu byl pověren kutnohorský státní zástupce Schneider-Svoboda, který se motivu rituální vraždy od počátku vyšetřování nijak nebránil. Ačkoli svědecké výpovědi svědčící proti Hilsnerovi byly značně nepřesvědčivé i nevěrohodné, rychle se rozhodl zúžit své vyšetřování pouze na Hilsnera a proti němu pak také podal u kutnohorského soudu obžalobu. ${ }^{8}$

V soudním řízení před krajským soudem v Kutné Hoře sehrál významnou roli JUDr. Karel Baxa, ambiciózní pražský advokát a zapřisáhlý antisemita, který zastupoval poškozenou Marii Hrůzovou, matku oběti. ${ }^{9}$ Hlavní zbraní dr. Baxy se brzy stala výpověd' zámečníka Petra Pešáka. Ten se až v srpnu 1899, tedy více než 4 měsíce od smrti Hrůzové, přihlásil, že onoho dne viděl u lesa Březina muže v šedém obleku s bílou holí v doprovodu dvou dalších mužů, ve kterém bezpečně rozpoznal Hilsnera. Pešákovo svědectví obsahovalo velkou řadu nesrovnalostí, které musely být zřejmé i široké veřejnosti. Své svědectví navíc několikrát mírně upravil. Skutečnost, že se svým svědectvím přišel až na počátku srpna, vysvětloval jednou strachem z reakce ženy, podruhé obavou ze ztráty svých židovských zákazníků. V neposlední řadě vyvolávala pochybnosti skutečnost, že Pešák měl Hilsnera vidět a rozeznat na vzdálenost 600 kroků, což se zdálo

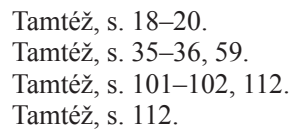


být velmi obtížné až nemožné. Přes to všechno se před soudem tvrdý a sebejistý Pešák stal klíčovým svědkem obžaloby.

Hilsnera u soudu zastupoval renomovaný kutnohorský advokát JUDr. Zdenko Auředníček, který se jeho obhajoby ujal dobrovolně, z přesvědčení o jeho nevině a ve snaze poukázat na absurdnost pověry o rituální vraždě. ${ }^{10}$ Auředníček byl před dvanáctičlennou porotou, která o vině Hilsnera rozhodovala, oproti soukromému žalobci Baxovi ve značné nevýhodě. Vedle energického Baxy, který sázel na emoce spojené s rituální vraždou, působil Auředníčkův kultivovaný a propracovaný, avšak stř́dmý a věcný projev na porotce méně přesvědčivě. Po pětidenním přelíčení Aư̌edníček ve své závěrečné řeči pečlivě rozebral a vyvrátil všechny údajné důkazy, které měly svědčit o Hilsnerově vině. Namítal, že dle údajů uváděných jednotlivými svědky nemohl být Hilsner vůbec na místě činu. Upozorňoval, že nikdy nevlastnil šedý oblek, v němž měl být údajně spatřen, a že se nikdy neprokázala obžalobou prezentovaná verze, že Hilsner provedl vraždu Anežky Hrůzové spolu s dalšími dvěma muži. Porotu se však Auředníčkovi o Hilsnerově nevině přesvědčit nepodařilo a 16. záŕí 1899 dospěla jednomyslně k závěru, že Hilsner byl jedním z pachatelů vraždy Anežky Hrůzové, a odsoudila jej k trestu smrti oběšením. ${ }^{11}$

Auředníček podal proti rozsudku zmateční stížnost a kasační soud ve Vídni rozhodnutí skutečně zrušil a nařídil obnovu trestního řízení. V rozhodování kasačního soudu se stal zásadním revizní lékařský posudek, jehož zpracování a předložení vídeňskému soudu pomáhal Auředníčkovi zajistit Tomáš Garrique Masaryk, toho času profesor pražské Karlovy univerzity, který se do procesu v této fázi také zapojil.

Obnovené rízení se již nekonalo v Kutné Hoře, ale aby byl proces odstíněn od dosavadních emocí, přesunuli jednání ke krajskému soudu v Písku. Ačkoli z kritických závěrů nálezu kasačního soudu vyplývalo, že v obnoveném řízení by mělo dojít $\mathrm{k}$ důkladné revizi dosavadního vyšetřování, i písecký proces od počátku vycházel z předpokladu, že se u Polné odehrála rituální vražda. Hilsner dokonce musel čelit i obvinění, že způsobil také smrt druhé mladé dívky, považované za Marii Klímovou, která se ztratila již před dvěma roky v létě 1898 , a teprve během kutnohorského procesu bylo nalezeno tělo, které mohlo patřit právě jí. Tělo považované za ostatky Klímové bylo nalezeno v lese, částečně obnažené a přikryté chvojím, což státního zástupce vedlo k rozšíření obžaloby o druhý trestný čin vraždy. V obnoveném ř́zení se objevili další svědci s velmi nevěrohodnými výpověd’mi, ve kterých detailně popisovali dva roky staré události z pouti v Březině. Hilsner se tam měl údajně s Marií Klímovou setkat a měli spolu strávit nějaký čas. A to navzdory tomu, že Hilsner byl prokazatelně toho dne poměrně daleko, u rodiny svého př́tele v Jihlavě. Státní zástupce si však s touto okolností nelámal hlavu a překlenul ji toliko konstatováním, že „Hilsner spěchajici na kř́dlech lásky ke Klímové mohl být ráno v Jihlavě a navečer již na pouti v Březine“ .12

Jednotlivé svědecké výpovědi v píseckém procesu si odporovaly, jeden svědek ho viděl zde a druhý vzápětí někde úplně jinde. Státní zástupce si však z každé výpovědi

\footnotetext{
10 Tamtéž, s. 155.

11 Tamtéž, s. 212-213.

12 Tamtéž, s. 442.
} 
pouze vybral to, co se mu hodilo, a časové rozpory odbyl závěrem, že „nepřesnostem $v$ časových údajích nelze prikládat větší význam". ${ }^{13}$

I podruhé tak byl Hilsner porotou odsouzen $\mathrm{k}$ trestu smrti. Opětovně za účast na vraždě Anežky Hrůzové, nově pak také za vraždu Marie Klímové a trestný čin na cti utrhání v souvislosti s křivým obviněním dalších dvou židů z vraždy Hrůzové, kterého se dopustil pod tíhou svého pobytu ve vazbě. Auředníček ani po prohraném procesu ve svém boji za spravedlnost pro svého značně netypického klienta neustal. Když byla jeho druhá zmateční stížnost zamítnuta, obrátil se na císaře s žádostí o milost a uspěl. Císař Franz Josef I. přeměnil trest smrti na trest doživotního žaláře. Díky pokračujícímu úsilí Auředníčka a tlaku významných osobností byl pak Hilsner po téměř dvaceti letech strávených za mř́žemi v roce 1918 díky milosti posledního rakousko-uherského císaře Karla I. propuštěn. ${ }^{14}$ Žil pak pod pozměněným jménem ve Vídni, kde v roce 1928 zemřel v chudobě, $\mathrm{v}$ zapomnění, aniž by došlo $\mathrm{k}$ očištění jeho jména.

Obvinění z rituální vraždy a následných soudů zažilo přitom tehdejší Rakousko-Uhersko na konci 19. století několik, v tom nebyl Hilsnerův př́pad nijak výjimečný. V českých zemích např. v Kolíně, Holešově, Rychnově nad Kněžnou, v Mad’arsku v Tizsa Eszlár, dále pak např. v ukrajinském Kyjevě. Scénáře těchto procesů se od sebe odlišovaly jen minimálně: žid je obviněn z rituální vraždy, dění před soudem přitahuje značnou pozornost místních i celé Evropy, před soudem vystupují významné osobnosti dané společnosti, odkazuje se na antisemitské stereotypy, obhajoby se mnohdy chopí význační a schopní advokáti. Vesměs ovšem soudy vydávaly osvobozující rozsudky a po několika měsících či letech pouštěly obžalované z vazby, $v$ řadě př́ípadů byly dokonce osoby, které vykonstruovaná obvinění vznesly, odsouzeny k několikaměsíčnímu vězení. Mezinárodně známou se stala zejména francouzská Dreyfusova aféra, ve které ovšem nešlo o obvinění z rituální vraždy, nýbrž špionáže. Její hlavní obětí se stal důstojník generálního štábu francouzské armády Alfred Dreyfus, který byl v procesu se silně rasistickým podtextem odsouzen roku 1894 a posléze rehabilitován. Antisemitismus začátku 20. století odrážejí také tzv. Protokoly sionských mudrců, poprvé publikované v ruském Petrohradě v roce 1903. Jedná se o podvodné dokumenty, které na základě smyšlených údajů konstruují konspirační teorii, podle které se židé chystají ovládnout svět. ${ }^{15}$ Př́pad Leopolda Hilsnera tak zůstává v českém i evropském kontextu ojedinělý. ${ }^{16}$

13 Tamtéž, s. 439-441.

14 NOVOTNÝ, L. JUDr. Auředníček - zapomenutá obět’ hilsneriády. KROK • Kulturní revue Olomouckého kraje, Olomouc, 2009, roč. 9, č. 4, s. 43-44.

15 Více viz např. https://www.holocaust.cz/dejiny/antisemitismus-2/antisemitismus-po-druhe-svetove-valce /teze-moderniho-antisemitismu-v-soucasnosti/protokoly-sionskych-mudrcu/.

16 KOSEK, J. Citadela nebo doupě; v zajetí ambivalence - zamyšlení nad některými zdroji a souvislostmi díla Franze Kafky. In: KYSELA, J. - URBAN, M. (eds.). Literatura a film jako zrcadlo práva a právníki̊. Praha: Leges, 2017, s. 84 a 89. Jan Kosek připomíná, že o kyjevském procesu, který proběhl v letech 1911-1913, napsal německy píšící, v Praze působící autor židovského průvodu, Franz Kafka, povídku. Krátce před smrtí ovšem nařídil její zničení. 


\section{PRÁVNĚ VÝZNAMNÉ SOUVISLOSTI HILSNEROVY AFÉRY}

Hilsneriáda brzy ztratila svůj lokální charakter a stala se celospolečenskou záležitostí. Mluvit a psát o ní přinášelo novinám čtenáře a politikưm volební hlasy, ustavil se ostatně okolo ní i specifický byznys s pohlednicemi a různými upomínkovými předměty. $Z$ našeho pohledu je ovšem mimořádně významné, že se její klíčová dějství odehrávala před právními institucemi a významné role v této tragédii na sebe více či méně dobrovolně převzali právníci. Jakou zprávu o působení práva a právníků ve společnosti na samém konci 19. století se z př́ípadu Hilsner dozvídáme? V následujícím textu představíme pět aspektů Hilsnerova př́ípadu, které považujeme pro právnické publikum za nejvýznamnější, a to jak s ohledem na tehdejší případ, tak fungování práva a právníků v dnešní době.

\subsection{VZTAH ADVOKÁTA A JEHO KLIENTA}

Celý př́pad předně poukazuje na zajímavá profesně-etická témata. Hilsnerův př́pad ukazuje, jak podstatnou roli pro obviněného, zejm. je-li vzat do vazby, sehrává jeho právní zástupce. Dobře to ostatně ilustruje např. nedávno Českou televizí natočený dvojdílný hraný film Zločin v Polné. Leopold Hilsner, nepř́liš inteligentní ani oblíbený mladík, ztratil po vzetí do vazby prakticky jakýkoli kontakt s vnějším světem. Zmatený sám od sebe, natož po uzamčení do cely, stal se jeho prakticky jedinou blízkou osobou a průvodcem tímto nesnadným časem jeho právní zástupce dr. Auředníček. Bez jeho vysoce nadstandardní právní i lidské pomoci, kterou navíc vykonával ex offo a za vytrvalého opovržení většinové české společnosti, by se Hilsner zřejmě zhroutil $a \mathrm{k}$ vraždě se přiznal (jak ostatně $\mathrm{v}$ jednom slabém okamžiku ve věznici i učinil a doznání pak na nátlak dr. Auředníčka následně odvolal), ne-li si rovnou sáhl na život.

Ačkoli počátky advokacie i nutné obhajoby vykonávané řečníky, př̌edchůdci advokátů, lze vypozorovat $\mathrm{v}$ českých zemích již ve středověku, ${ }^{17} \mathrm{k}$ výraznějšímu rozvoji institutu nutné obhajoby došlo právní úpravou v zákoně č. 119/1873 ř. z., jímž se zavádí nový rád soudu trestního spolu se zákonem č. 96/1868 ř. z., kterým se uvádí rád advokátský. Institut nutné obhajoby byl pritom v této době v Rakousku-Uhersku ve svých úplných počátcích. Oba zákony lze dnes však označit za značně progresivní, druhý uvedený se dokonce stal inspirací při formulaci nové, polistopadové právní úpravy advokacie. ${ }^{18}$ Hilsnerův případ nám připomíná, že skutečnost, že náš právní systém zaručuje obhájce i těm, o jejichž vině málokdo pochybuje, je třeba považovat za jeho přednost a nikoli slabost. Stát, který prostřednictvím státního zástupce obžalovává údajného pachatele, se nachází ve zřetelné převaze, zejména viní-li z porušení pravidel soužití prostáčka Hilsnerova typu. Vyspělost právního státu se $\mathrm{v}$ takovýchto př́padech pozná nikoli podle vysokého procenta odsouzených pachatelů či př́snosti trestů, ale dle poskytovaných právních záruk, včetně práva na kvalitní obhajobu, které stát coby zřetelně

${ }^{17}$ Historie advokacie v C̆R, https://www.cak.cz/scripts/detail.php?id=38.

18 VYCHYTA, J. Obhájce v trestním ř́zení, diplomová práce. Univerzita Karlova v Praze, Právnická fakulta, Praha, 2013, s. 3. 
silnější hráč obviněným zajistí. A to i s vědomím rizika zneužití této zdánlivé slabosti státu. ${ }^{19}$

Hilsnerův př́ípad nepatřil v žádném ohledu $\mathrm{k}$ těm typickým. Probíhal za mimořádného zájmu a účasti veřejnosti, a to i mezinárodní, přičemž vox populi od počátku netrpěl žádnou pochybností co do Hilsnerovy viny. Nepř́liš bystrý a charakterově nepevný Hilsner, který z velké části nechápal, do jakého dění byl vlastně vtažen, nerozuměl právní dimenzi svého procesu a zjevně nepř́liš úspěšné byly i pokusy jeho právního zástupce svého klienta průběžně seznamovat se svojí právní taktikou. Film Zločin v Polné nám nabízí scény, kdy advokát poučuje svého klienta, jak má u soudu vystupovat, co ř́kat a čemu se raději vyhnout. Počíná si logicky, přesto tím otevírá otázku, do jaké míry je advokátovi dovoleno instruovat svého klienta, a to i klienta nepř́liš bystrého. Vyjdeme-li z aktuální právní úpravy, zákon o advokacii advokátovi přikazuje „chránit a prosazovat práva a oprávněné zájmy klienta a ř́dit se jeho pokyny“, které nemusí poslouchat toliko v př́padě, že jsou v rozporu s právními či stavovskými předpisy. ${ }^{20}$ Dále jsou advokáti povinni ,jednat čestně a svědomitě a v rámci dostupných zákonných prostředků uplatnit vše, co podle svého přesvědčení pokládají za prospěšné. Zákonná hranice dovoleného je tedy poměrně široká a vylučuje jen např. křivé obvinění jiného či možnost obviněného radit se s obhájcem, jak odpovědět na již položenou otázku. ${ }^{21}$ Koneckonců, vinu obviněného má dokazovat státní zástupce a posuzovat soud, právní zástupce obžalovaného má stát na jeho straně, a dokud si počíná férově, může usilovat o jeho osvobození či zmírnění trestu všemi dostupnými prostředky.

Z pohledu právní etiky se na Hilsnerově prŕípadu jako významné ukazuje i téma důvěry mezi klientem a jeho advokátem. Pokud se právní zástupce, který nadto vykonává své služby zdarma a musí snášet opovržení svého okolí, nemůže spolehnout na to, že ho jeho klient pravdivě seznámil se vším, co o dané věci ví, dává smysl, že mu stavovské i zákonné předpisy umožňují obhajobu ukončit. Zatímco klient může spolupráci s advokátem ukončit kdykoli a prakticky z jakéhokoli důvodu, advokátovi coby profesionálovi, který má být schopen dopředu svého klienta a celý př́ípad alespoň v základních parametrech odhadnout, umožňují předpisy ukončit obhajobu jen v některých př́padech, mezi které patří právě ztráta důvěry mezi klientem a jeho právním zástupcem. Musí se pochopitelně jednat o relevantní ztrátu důvěry, kterou na požádání bude advokát schopen doložit napřs. rozporuplností klientových výpovědí či poskytnutých informací. ${ }^{22}$

19 Široce pojaté právo na spravedlivý proces nutně umožňuje obžalovaným využívat celou řadu procesních nástrojů, jejichž kombinace může v některých případech hraničit až se zneužíváním tohoto práva - mohou např. neúměrně natahovat či dokonce obstruovat průběh řízení. Jiní obžalovaní zase mohou být do té míry vybaveni penězi, že žádnou pomoc od státu de facto nepotřebují, nebot' pro ně pracuje armáda najatých advokátů. Tím pochopitelně netvrdíme, že s obstrukcemi se právní systém nepotýkal již v dřívějších dobách.

$20 § 16$ odst. 1 zákona č. 85/1996 Sb., o advokacii.

21 Srov. trestný čin křivé výpovědi definovaný v $\$ 345$ trestního zákoníku č. 40/2009 Sb. a $\S 33$ odst. 1 trestního řádu č. 141/1961 Sb.

22 Srov. § 20 odst. 2 zákona č. 85/1996 Sb., zákon o advokacii. 
Současný český justiční systém spočívá zejména na profesionálních soudcích. Laický prvek zajišstují př́ísedící, kteří se účastní prvoinstančního rozhodování $\mathrm{v}$ trestních a pracovněprávních záležitostech. ${ }^{23}$ Jak nás nicméně učí studium právní historie, poroty coby tradiční a významný prvek soudních procesů nenáleží jen $\mathrm{k}$ angloamerické právní kultuře, ale od poloviny 19. do poloviny 20. stolení se vyskytovaly i v řadě zemí s kontinentální právní tradicí jako např. v Německu, Rakousku, Francii, Belgii i Československu. V těchto zemích poroty rozhodovaly obvykle jen o nejzávažnějších zločinech, a měly tak logicky ukládat nejzávažnější tresty včetně trestu smrti. Nezř́idka se tak stávalo, že porota mohla cítit př́liš velkou tíhu odpovědnosti za život člověka a rozhodla navzdory usvědčujícím důkazům raději o zproštění pachatele viny, aby nemusela $\mathrm{k}$ uložení tohoto trestu přistoupit. ${ }^{24}$ I Leopold Hilsner byl jak v Kutné Hoře, tak i při novém projednání svého př́ípadu soudem v Písku souzen porotou složenou z právních laiků.

Poroty historicky vznikly jako pojistka proti zneužívání síly ze strany vládnoucí moci. O vině a nevině nerozhodoval zástupce panovníka či šlechtice, který soud ustanovil, ale sbor svobodných občanů dané komunity. I oni se jednou mohli ocitnout na lavici obžalovaných, což je nepochybně motivovalo vykonávat svůj úkol pokud možno odpovědně. Právní praxe se ovšem může od teorie značně odlišovat. Po zhlédnutí právní filmové klasiky 12 rozhněvaných mužů režiséra Sidneyho Lumeta, která zobrazuje nelehké a zejména pak vyvíjející se rozhodování poroty $\mathrm{v}$ př́ípadě z vraždy obžalovaného mladého muže, je jen málokterý divák přesvědčen o tom, že by chtěl raději být souzen porotou než profesionálními soudci. Nesmíme zapomínat ani na stádní efekt, kterému mají lidé tendenci ve skupině podléhat, a na všeobecnou tendenci ke konformitě se skupinou či předepsanými pravidly. ${ }^{25}$ Ani relativně veliký počet dvanácti tedy nemusí zaručovat, že se ve vybraném vzorku běžné populace najde jedinec, který tváří v tvár̆ nepochybující porotní většině dokáže zformulovat a obhájit své pochybnosti. O nesnad-

23 Srov. KÜHN, Z. Laický prvek v justici-archaismus v 21. století nepotřebný? In: Jiné právo [online] 3. 10. 2008. Dostupné na: http://jinepravo.blogspot.cz/2008/10/laick-prvek-v-justici-archaismus-v-21.html.

24 GORPHE, F. Reforms of the Jury-System in Europe: France and Other Continental Countries. Journal of Criminal Law and Criminology, 1936, vol. 27, č. 2. s. 158, 162-163.; Zdeněk Kühn k tomu poznamenává, že ,,v revolučním roce 1848 byla demokratická kontrola justice prostřednictvím porot jedním z důležitých požadavků demokratických sil“", načež v „omezené podobě začaly poroty fungovat v 50 . letech 19. století“, přičemž porota rozhodovala i známý proces s Karlem Havlíčkem Borovským. Jakkoli institut porot znala československá ústavní listina z roku 1920, bylo porotní soudnictví terčem kritiky ze strany soudcovské veřejnosti již od 20. let pro svoji neekonomičnost, iracionalitu a zbytečnost. Srov. KÜHN, Z. Laický prvek v justici - archaismus v 21. století nepotřebný? Rozhodování porot v prvorepublikovém Československu zachycují také např. Povídky z jedné kapsy a Povídky z druhé kapsy Karla Čapka. Srov. URBAN, M. Starý dobrý právnický svět Karla Čapka. In: KYSELA, J. - URBAN, M. (eds.). Literatura a film jako zrcadlo práva a právníkủ. Praha: Leges, 2017.

25 Skupinová dynamika, ochota chovat se v souladu s ostatními i tendence podřizovat se pravidlům a autoritě byly popsány a doloženy např. americkými psychology Philipem Zimbardem v jeho slavném stanfordském experimentu, Stanley Milgramem v neméně slavném experimentu s elektrickým proudem, který měl údajně pomáhat žákům v učení, nebo Solomon Eliot Aschem, který pro svůj test konformity využil jednoduché porovnávání velikosti čar ve skupině. Započíst jistě můžeme i vliv skupinového myšlení (groupthink), které vede jednotlivce ke konformitě se skupinou i v situacích, kdy vnitřně s názorem skupiny nesouhlasí. Obecně tendenci jedince podléhat společenským vlivům, které ho obklopují, studuje sociální psychologie. 
nosti takového počínání ostatně dobře vypovídá již zmíněný snímek 12 rozhněvaných mužù.

Podobně tak Hilsnerův př́ípad ukazuje, jak nesnadný úkol mají porotci zejména v mediálně vypjatých prípadech, kdy hlas ulice, tisku, ale vlastně téměř celé společnosti má o vině obžalovaného jen pramálo pochybností. ${ }^{26}$ Je vůbec možné od prostých mužů sedících na lavicích určených porotcům očekávat, že se postaví veřejnému mínění? O svoji nezávislost musí pochopitelně bojovat i profesionální soudci. Jakožto profesionálové s patřičnou př́pravou, letitými zkušenostmi, autoritou svého úřadu a oporou ve svých kolezích $\mathrm{k}$ tomu ovšem mohou nacházet odvahu i sílu nesrovnatelně snáze než laičtí muži (a dnes již i ženy) z lidu.

V Hilsnerově př́padě na ovlivnitelnost poroty upozorňuje samotný kasační soud ve Vídni, který zrušil rozsudek soudu v Kutné Hoře. Kasační soud se ve velké míre opřel o lékařský posudek vyhotovený pražskou lékařskou fakultou a pojmenoval problematické momenty kutnohorského rozsudku. Upozornil na nejasnosti ohledně počtu pachatelů, množství nalezené krve, domnělých skvrn od krve na Hilsnerových kalhotách, zmínil ovšem i otázku správné informovanosti porotců. V jeho rozhodnutí se tak můžeme dočíst, že ,porotci v Kutné Hoře podléhali vlivům, které mohly mít vliv na finální rozhodnutí poroty“ a upozornil, že jim důkazní materiál byl předkládán „, nesprávném světle“. 27

Institut porot byl na území dnešní České republiky zaveden nejprve na krátkou dobu prozatímním řádem trestním vydaným Františkem Josefem I. v roce 1850. Avšak přijetím silvestrovských patentů o rok později a nástupem tzv. Bachova absolutismu došlo záhy $\mathrm{k}$ jejich zrušení. ${ }^{28} \mathrm{~K}$ jejich opětovnému zavedení s trvalejší platností pak došlo výše zmíněným trestním řádem v roce 1873 . Ke zrušení porot pak došlo zákonem č. 319/1948 o zlidovění soudnictví. Je pochopitelně lákavé přemýšlet o tom, jak by Hilsnerův proces dopadl, kdyby výřečný dr. Baxa přesvědčoval před zraky nadšeného publika nikoli muže z lidu, ale soudní senát složený z profesionálních soudců. Nepochybně ani soudci z povolání nejsou imunní vi̊či mediálnímu tlaku, přece jen jsou ale soudním aparátem i svými zkušenostmi lépe vybaveni ho snášet.

\subsection{ZPƯSOB SHROMAŽĎOVÁNÍ DƯKAZU゚}

Významný vliv na Hilsnerův proces měl i speciální právní výbor, který z vlastní iniciativy zř́ídili radní města Polná. Jeho členové vyslýchali svědky a vedli „vyšetřování“. Jakožto ryze politická instituce, kterou zrrídili a spravovali představitelé exekutivy města Polná, ovšem neusiloval o objektivitu. Právě naopak, z vyjádření

${ }^{26}$ Mediální tlak měl přitom v Hilsnerově př́ípadě vedle dobře představitelné podoby (články v novinách, shromáždění v ulicích, jednoznačně naladěná veřejnost v soudní síni) i méně představitelnou podobu. Vražda Anežky Hrůzové se stala obchodním trhákem. Vydávaly se a ve velkém prodávaly pohlednice připomínající událost. Dále se o události v Polné začaly zpívat tzv. „kramářské písně“ tradičně vyprávějící určitý př́běh či zážitek, které se brzy staly hitem a zpívaly se na Moravě hojně ještě po druhé světové válce. Dokument Případ Leopolda Hilsnera, Díl první, Tajuplná vražda, 30. Minuta. VAŘEJČKA, R. Hilsneriáda, diplomová práce. PedF MU Brno, 2011, s. 66-67.

27 KOVTUN, J. Tajuplná vražda: Př́pad Leopolda Hilsnera, s. 359.

28 SCHELLE, K. Vývoj trestního ř́zení. Ostrava: Key Publishing, 2012, s. 30-31. 
starosty města Sadila, který byl vedle dalších členů městské rady jedním z iniciátorů i koordinátorů výboru, nelze mít pochybnosti o jeho antisemitském zaměření. ${ }^{29}$ Právní výbor potřeboval vykázat rychlé výsledky svého šetření, a tak velmi záhy soustředil svoji aktivitu zejména na dokazování viny Hilsnera, notně v tom popoháněn hlasem místních. Poptávkou po nových svědcích a jejich neprofesionálním, silně tendenčním způsobem výslechu ve skutečnosti pomáhal tento ,právní“ výbor šírit přesvědčení o Hilsnerově vině a povzbuzoval další svědky, aby potvrzovali základní narativ celého případu. Snahu přičinlivých místních povzbuzoval výbor i vypsáním odměny, která nicméně spíš než nová, neřku-li pravdivá fakta přinesla záplavu lidí, kteří byli ochotni svědčit i o skutečnostech, které se prokazatelně stát nemohly. Právní výbor pak výsledky svých rozličných aktivit dodával nejprve antisemitskému tisku, kterým byly kupř́kladu Radikální listy, potom Karlu Baxovi a nakonec i prŕmo soudu, který postřehy právního výboru bohužel ochotně zařazoval do soudního spisu. Existence tohoto výboru, který svou ingerencí bezesporu zcela zásadě a negativně ovlivnil průběh vyšetřování i soudního řízení, nám připomíná, jak významné je oddělit orgány činné v trestním ř́zení, at' již jde o policii, státní zastupitelství či soudy, od aktuální vládnoucí politické většiny. Teprve soustavná, na vládnoucí moci nezávislá a důvěru vzbuzující práce orgánů činných v trestním řízení přispívá $\mathrm{k}$ fungování právního státu. ${ }^{30} \mathrm{Na}$ druhé straně, jak bude později demonstrováno na zapojení profesora Masaryka do celé aféry, nelze jednoduše konstatovat, že aktivity občanské společnosti jsou pro fungování spravedlnosti bez dalšího vždy nežádoucí a zhoubné. Lze zcela jistě nalézt i př́pady, kdy má vliv veřejnosti na uplatňování práva účinky pozitivního rázu. V současné době se můžeme setkat kupř́kladu s tzv. strategickou litigací, při níž se neziskové organizace či jiné zájmové skupiny angažují v konkrétním případě s tím, že jeho výsledek pozitivně dopadne na skupinu lidí ve stejné situaci. ${ }^{31}$

Jak již bylo naznačeno výše, významnou roli sehrály v procesu i svědecké výpovědi. Známý bonmot tvrdí, že svědek je osoba, která věc viděla, ale nerozumí jí ${ }^{32} \mathrm{~V}$ Hilsnerově př́padu byl ovšem nejprve městský právní výbor a posléze vyšetřovatelé a soudci konfrontováni s některými svědky, kteří čin - i pokud by ho Hilsner opravdu spáchal - zřejmě neviděli, navíc svým svědectvím a zejména pak očekáváním, že přispějí k odsouzení Hilsnera, pomáhali de facto činit rozhodnutí. Nejvýrazněji v tomto ohledu působí osoba korunního svědka, Petra Pešáka. Tento několikrát za drobné přestupky trestaný muž se sice objevil až po čtyřech měsících vyšetřování, svým tvrzením o tom,

29 KOVTUN, J. Tajuplná vražda: Př́pad Leopolda Hilsnera, s. 69-70.

30 To si ostatně uvědomovali i klasici amerického politického systému. Srov. HAMILTON, A. - JAY, J. MADISON, J. Listy federalistů: soubor esejí psaných na podporu nové Ústavy předložené federálním Shromážděním 17. záři 1787. Olomouc: Vydavatelství Univerzity Palackého, 1994, zejména pak list č. 78, s. 414-415.

31 Dopady strategické litigace: Desegrace Romů ve školství, Open Society Justice Iniciative, dostupné na: http://osf.cz/wpcontent/uploads/2016/04/OSJI_Dopady_strategicke_litigace_Desegregace_Romu_ve skolstvi_CZ.pdf, s. 10.

32 Autorství celého výroku Václav Štaud ve své diplomové práci s názvem Svědek v trestním řízení připisuje dr. Vaňkovi: „Svědek je člověk, který věc viděl, ale nerozumi jí. Znalec je člověk, který věc nevidèl, ale rozumí ji. Soudce je člověk, který věc nevidèl, nerozumi ji, ale rozhoduje o ní. "ŠTAUD, V. Svědek v trestním řizení, bakalářská práce. Právnická fakulta Masarykovy univerzity v Brně, 2010, s. 2. Dostupné na: https:// is.muni.cz/th/285294/pravf_b/Bakalarka_SVEDEK_v_TR.txt. 
že bezpečně na úctyhodnou vzdálenost poznal v postavě na obzoru Hilsnera, umožnil soudu vynést odsuzující verdikt. Osoba zámečníka Pešáka i ostatních místních, jak je vděčně zobrazuje film Zločin v Polné, nás upomínají na to, jak nespolehliví a nedůvěryhodní umí svědci být. Pamět' jim má tendenci selhávat, přejímají názor svého okolí či mediálního světa, snáze věří skutečnostem, které potvrzují a nikoli vyvrací jejich vnímání reality, ${ }^{33}$ zkušení advokáti či soudci je při výslechu dokáží dobře kladenými otázkami navést tam, kde je potřebují mít. Někteří se pak nechají prrímo koupit. Polenský případ nám připomíná, že ani těm, kteří vše ,viděli na vlastní oči a slyšeli na vlastní uši“, není radno slepě věřit, u vypjatých a mediálně sledovaných případů pak dvojnásob. Lidské smysly, jak nás upomínají např. nejrůznější optické klamy, se dokáží mýlit tak zásadním způsobem, že bez kritického posuzování jednotlivých svědectví a zejména pak konfrontování všech důkazů a jejich souhrnného posouzení není možné dosáhnout spravedlivého rozsudku. ${ }^{34}$ Nemají to koneckonců být naše smysly, které rozhodují, ale lidský rozum.

\subsection{OBRAZ FUNGOVÁNÍ TEHDEJŠÍ PRÁVNICKÉ A INTELEKTUÁLNÍ OBCE}

Oba procesy s Leopoldem Hilsnerem nám také umožňují nahlédnout do fungování dobové právnické obce. V českých zemích konce 19. století, stejně jako ve Spojených státech amerických platilo, jak si všímá americký politolog Fareed Zakaria, že právníci představovali ,privilegovanou a na veřejnou činnost orientovanou elitu...". Patřili mezi ,přední občany, kteř́ pomáhali budovat muzea a nemocnice, utváreli občanské instituce a zastávali v mistní správě postavení na všech úrovních" “. ${ }^{35} \mathrm{Již}$ Tocqueville se domníval, že právě relativně dobře zajištění a společností respektovaní právníci se mohou stát těmi, kdo zabrání „tyranii většiny“, nebot' nejsou na nikoho vázáni, a proto jim lze svěřit starost o prospěch veřejnosti. ${ }^{36}$ Zakaria i jiní v tomto ohledu podtrhují roli omezeného vstupu do advokátní profese: „V každém městě působil jen omezený počet právních firem. Vstoupit na trh bylo obtižné. Těm, kdo na něm podnikali,

33 Výzkumy ukazují, že instinktivně přijímáme ty informace, které odpovídají tomu, co si myslíme. Abychom rozpoznali, že je nějaká informace mylná, musíme vyvinout extra úsilí. Máme proto sklon si myslet, že známá informace je pravdivá, a z okolní reality si vybíráme ty informace, které podporují naše existující názory. Psycholog a nobelista Daniel Kahneman naši tendenci vyhýbat se faktům, která by náš mozek nutila k větší námaze, nazývá „,kognitivní pohodlností“. Dokonce se stává, že když nás někdo konfrontuje $\mathrm{s}$ fakty uvádějícími věci na pravou míru, může to naše přesvědčení paradoxně ještě utvrdit. Výzkumníci z Brendan Nyhan z univerzity Dartmouth College a Jason Reifler z Exeterské univerzity tomu ríkají ,zpětný efekt". Srov. Yes, I'd lie to you: Dishonesty in politics is nothing new; but the manner in which some politicians now lie, and the havoc they may wreak by doing so, are worrying. The Economist [online]. 2016 [cit. 8. 8. 2017]. Dostupné na: https://www.economist.com/news/briefing/21706498-dishonesty-politics -nothing-new-manner-which-some-politicians-now-lie-and.

$34 \mathrm{Na}$ nespolehlivost paměti upozorňuje např. kniha psycholožky SHAW, J. Iluze paměti: falešné vzpomínky a proč jim věřme. Praha: Paseka, 2017. Nedostatky v našem vnímání popisují a empiricky prokazují i autoři projektu The Invisible Gorilla. Srov. CHABRIS, Ch. F. - SIMONS, D. J. The Invisible Gorilla: and Other Ways Our Intuitions Deceive Us. New York: Crown, 2010. Podobně tak v této souvislosti nelze nedoporučit knihu THALER, R. H. - SUNSTEIN, C. R. Nudge: Improving Decisions about Health, Wealth and Happiness. London: Penguin Books, 2009.

35 ZAKARIA, F. Budoucnost svobody. Praha: Academia, 2004, s. 282. Př́íladnou osobou v tomto smyslu byl obhájce Hilsnera, dr. Auředníček. Srov. NOVOTNÝ, L. JUDr. Auředníček - zapomenutá obět hilsneriády.

36 Tamtéž, s. 283. 
se dařilo dobře, ale nesnažili se zvyšovat ceny. Právo bylo prostorem k slušnému a vysoce respektovanému způsobu života, nikoli však prostorem, v němž se dá zbohatnout. Oceňován byl stabilní trh s pravidelným a předvídatelným ziskem. Struktura napodobujicí kartel také zajištovala, že právníci měli dost času, aby mohli sledovat veřejné zájmy.“37

Hilsnerův př́pad ovšem ukazuje, že ani právníci s př́stupem „k slušnému a vysoce respektovanému způsobu života" nezabránili tragédii, jakou představoval prŕpad Hilsner. Úkolem právníků, kteří možná o něco zřetelněji ve Spojených státech, ale nepochybně i v Rakousku-Uhersku přirozeně tvoří součást lokálních elit, má být odolat prrání veřejnosti a dokázat uhájit základní podobu spravedlnosti i přesto, že jí aktuální společenská poptávka nepřeje, či si dokonce přeje pravý opak. K tomu ovšem nedošlo, resp. nedošlo u naprosté většiny hlavních protagonistů. $V$ tomto náročném testu obstál jen právní zástupce obžalovaného, dr. Auředníček. Soudci a zejména pak právní zástupce matky zavražděné, dr. Baxa, naopak plně naskočili na antisemitskou vlnu, nebo ji dokonce pomáhali aktivně vyvolávat. Je to pochopitelné z lidského hlediska (právníci jsou koneckonců také jen lidmi a lidé chybují a ustupují tlakům) a dobře sociologicky vysvětlitelné (naprostá většina lidí vědomě i nevědomě přijímá normy svého okolí, socializuje se, vzepřít se okolí stojí velké úsilí), nicméně úkol elit spočívá právě v tom tyto lidské i společenské vlivy překonávat ve jménu vyšších hodnot - např́íklad právě spravedlnosti.

Přemýšlíme-li o Hilsnerově procesu v širších souvislostech, vyvstává před námi mimořádně pochmurný obrázek tehdejší společnosti, paradoxně společnosti, která se pyšnila svým technologickým pokrokem a vzrůstající racionalitou. V prvé řadě jsme samozřejmě svědky osobní tragédie Leopolda Hilsnera, velmi pravděpodobně nevinného člověka, který se shodou náhod a za mohutného přispění antisemitské veřejnosti dostal do soukolí událostí, kvưli kterým strávil téměř dvě desetiletí ve vězení. Hilsnerův př́iběh se osudově protnul s předčasně a násilně ukončenými životy Anežky Hrůzové a později i Marie Klímové, dvou zavražděných mladých žen z okolí Polné, za jejichž vraždy kutnohorský a později i písecký soud odsoudily právě Hilsnera, ale skuteční pachatelé zřejmě trestu unikli. Neblahý dopad měly procesy s Hilsnerem i na jeho právního zástupce dr. Auředníčka. Jakkoli podle všeho odvedl nadstandardně kvalitní práci, shromáždil řadů důkazů zpochybňující svědecké výpovědi a Hilsnerovu vinu a v celém procesu sehrával roli jednoho z mála racionálně uvažujících lidí, skončil poražen. Nikoli jen u obou soudů, ale i lidsky. Musel se odstěhovat z Kutné Hory, kde měl svoji advokátní praxi, a na Masarykovu radu odešel v roce 1902 do Vídně. Jen malým zadostiučiněním mu mohlo být, že nakonec vymohl pro svého klienta milost. ${ }^{38}$

Celá událost měla dopad i na židovskou komunitu v Polné, která se po procesu z města částečně odstěhovala, jakkoli hilsneriáda nepředstavovala jediný důvod pokle-

37 Za pozornost stojí, že tento právnický svět se začal rozpadat poté, co do něj začali přistupovat noví lidé a kdy Nejvyšší soud v roce 1977 dovolil právníkům své služby inzerovat. To zvýšilo konkurenci a postupně vytvořilo kompetitivní trh právních služeb, na kterém pro samou honbu za klientem nezůstává čas na péči o věci společné. ZAKARIA, F. Budoucnost svobody, s. 284.

38 NOVOTNÝ, L. JUDr. Auředníček - zapomenutá obět' hilsneriády, s. 42-44. 
su počtu židovských obyvatel. ${ }^{39}$ Polná přitom v rámci tehdejšího rakousko-uherského mocnářství představovala zcela obyčejné, ničím, a to ani mírou antisemitismu, vyčnívající město. Polenská aféra mohla proběhnout prakticky kdekoli, kde by se okolnosti sešly podobně jako v Polné. To ostatně odpovídá i Masarykovu zjištění, který o obyvatelích Polné napsal, že to jsou „,milí lidé..., ale sedla na ně ta pověra a vybijeji židưm okna a snad by je i byli zbili ${ }^{“} .{ }^{40}$ Antisemitismus byl ovšem v časech našeho národního obrození a křísení českého vlastenectví mnohými považován za žádoucí projev vlastenectví. Od židů, podobně jako od Němců, jsme se přeci měli čeho obávat, domnívali se nejen tehdy mnozí. Navíc na konci 19. století představovali pro Čechy židé vlastně Němce. Jejich děti obvykle navštěvovaly německé školy, tři čtvrtiny židů žijících v Praze při censu v roce 1890 označily němčinu za jazyk, kterým běžně hovoří. ${ }^{41}$ Není tak divu, že toto židovské menšině česká veřejnost v době bojů za jazykovou a kulturní rovnoprávnost, který vyvrcholil německými protesty proti Badeniho jazykovým nařízením, ${ }^{42}$ nemohla odpustit.

Obvinění z rituální vraždy představovala jen špičku pomyslného ledovce. Lidový antisemitismus se potkával s antisemitismem českých elit, který nacházel živnou půdu prakticky ve všech oblastech společenského života. Zvlášt' aktivní roli v tomto sehrávali mnozí katoličtí duchovní, kteří v boji proti židovskému nebezpečí neváhali opouštět své křest’anské principy. Např́klad kněz Rudolf Vrba sepsal brožuru Pravda o procesu $v$ Polné, která se šírila ve vysokých nákladech a utvrzovala své čtenáře v nebezpečnosti židů. ${ }^{43}$ Vedle zástupců církve podporovali a probouzeli antisemitismus v Čechách také čeští nacionalisté a většina politických stran. Před volbami do Řišské rady v roce 1897 se antisemitská propaganda stala zásadním tématem předvolebního boje a i po nich ve veřejném životě toto téma intenzivně rezonovalo. ${ }^{44}$

Hilsnerův proces odhalil slabost české inteligence, která až na výjimky nedokázala odolat pokušení antisemitismu, mnozí ho navíc nejen pasivně tolerovali, ale velmi aktivně pomáhali šírit. Pokud již nebezpečné pohádce o zlém židovi, který potřebuje

39 Srov. KOSEK, J. Citadela nebo doupě; v zajetí ambivalence - zamyšlení nad některými zdroji a souvislostmi díla Franze Kafky. In: KYSELA, J. - URBAN, M. (eds.). Literatura a film jako zrcadlo práva a právníků, s. 86. Jak se dočteme v hesle Židovská komunita v Polné na české Wikipedii, v roce 1841 v Polné žilo 557 židů, v roce 1921 potom jen 67 . V roce 1938 udělila Polná domovské právo několika židovským rodinám z Vídně, které musely prchnout před nacisty. V roce 1942 muselo všech 63 polenských židů odejít do transportů. Přežili tři, žádný z nich se ovšem do Polné nevrátil. Dostupné na: https://cs.wikipedia.org /wiki/\%C5\%BDidovsk\%C3\%A1_komunita_v_Poln\%C3\%A9\#cite_ref-10. Nejednalo se o jediný incident. V Polné proběhl pogrom proti židům: $\overline{10} . \overline{4} .1899$ došlo k útoku na židovské domy a obchody. Městem táhlo asi 300 lidí, provolávali antisemitské hesla, rozbíjeli okna a výkladní skříně. Zasáhnout muselo místní četnictvo, ale protože dav nezvládlo, muselo povolat posily v Kutné Hory, která však dorazila až druhý den ráno. Dokument Př́ípad Leopolda Hilsnera, Díl první, Tajuplná vražda, 21. minuta.

40 Dokument Hilsnerova aféra, Česká televize, 2006, dostupný na http://www.ceskatelevize.cz/ivysilani /10114392043-hilsnerova-afera/206542152000001/titulky, 15. minuta.

41 CURTIS, M. The Hilsner Case and Ritual Murder. Human Rights Review, duben 2004, roč. 5, č. 3, s. 59.

42 Jazyková nařízení ministra Badeniho z roku 1897 přinesla dočasné zrovnoprávnění zemských jazyků, tj. češtiny s němčinou při kontaktu s úřady.

43 KOSEK, J. Citadela nebo doupě; v zajetí ambivalence, s. 83. Mezi velké katolické antisemity patřili také německy mluvící duchovní či teologové, jako např. jeden z hlasitých šiřitelů pověry o rituálních vraždách, teolog August Rohling.

44 FRANKL, M. The Background of the Hilsner Case. Political Antisemitism and Allegations of Ritual Murder 1896-1900. Judaica Bohemiae, s. 58-60. 
nevinnou křest’anskou krev do velikonočních macesů, neodolali prostí lidé, měla se proti této pověře postavit česká inteligence. Novináři uvádějící věci na pravou míru, politici tlumící vášně, právníci vedoucí emocí oproštěný, na fakta zaměřený a ve výsledku spravedlivý proces. Bohužel, až na čestné výjimky v tomto, jak trefně poznamenal vydavatel časopisu Čas Jan Herben, ,inteligence česká propadla ve zkoušce z inteligence“. Dokonce i vysokoškolští studenti, tento sice dlouhodobě nespolehlivý, ale v kritických okamžicích dobře reagující element české společnosti, bojkotovali Masarykovy přednášky a zřejmě se uchýlili i k inzultaci profesora Karlovy Univerzity. ${ }^{45}$

Jako mimořádně významný rozdmýchávač antisemitských nálad se ukázal již zmiňovaný JUDr. Karel Baxa, přední postava českého světa politiky a práva. Synovec Karla Havlíčka Borovského, v čase Hilsnerovy aféry již poslanec Českého zemského sněmu, význačný předválečný i prvorepublikový politik a veřejný činitel, ${ }^{46} \mathrm{v}$ letech $1921-1938$ první předseda československého ústavního soudu, dlouholetý starosta a primátor Prahy (1919-1937). ${ }^{47}$ Do procesu se připojil jakožto právní zástupce matky zavražděné Anežky Hrůzové, ale do značné míry převzal roli státního zástupce. Před soudem se neostýchal mluvit o židech jako o „odporné rase“ a celý proces soudci shrnout tak, že „,chtěli zavraždit křestanskou osobu, nevinnou dívku, aby z ní dostali krev. Všechno zamlouvání nic nepomáhá, ten účel vraždy zde byl. Světem běži zvěst, že jsou lidé, kteř́ usiluji o bezživotí bližnich, aby se zmocnili jejich krve. Je to přišerné, strašlivé. Člověk se vzpírá tomu uvěrit, my nevěríme pověstem a prece stojíme pred faktem, které je dokázáno, které se nedá vyvrátit." "48 Patří přitom ke smutné skutečnosti, že Baxa nepatřil ke zbabělcům, kteří dokáží toliko vycházet vstř́í přání lidu. Jinou, daleko ušlechtilejší podobu svého vlastenectví dokázal jak před hilsnerovou aférou v procesu s tzv. Omladinou roku 1894, ale i poté, když po roce 1933 odmítl z důvodné obavy z propagandistického zneužití vydat Hitlerovi akta k př́padu Hilsner. ${ }^{49}$

\subsection{MASARYKOVO ANGAŽMÁ}

Prapor tehdejší inteligence držel vedle vytrvalého dr. Auředníčka především Tomáš Garrigue Masaryk. Jeho angažování v celé věci působí téměř neuvěřitelně. Hilsnerovým př́padem se nemusel zabývat z úřední povinnosti, otázky kriminalistiky a trestního soudnictví vůbec nepatřily $\mathrm{k}$ jeho profesní expertize, nebylo mu nikým uloženo o Hilsnerově př́padu psát do novin. Jakožto sociolog a filosof, a zejména pak veřejný intelektuál ale chápal, že Hilsnerova kauza přesáhla kontext jednotlivého případu a získala celospolečenskou důležitost. Pro Masaryka v sobě polenský proces koncent-

45 Srov. KOSEK, J. Citadela nebo doupě; v zajetí ambivalence, s. 85, a Masarykova slova z časopisu Čas ze 4. března 1914: „Tenkrát nejen studentstvo, nýbrž i universita se podrobila nekulturnímu tlaku antisemitské ulice... “ Srov. OPAT, J. Masaryk - kritik rasismu. In: Kolektiv autorů. Hilsnerova aféra a česká společnost 1899-1999. Praha: židovské muzeum v Praze, 1999, s. 42.

46 Spolu s Aloisem Rašínem založil Stranu státoprávně radikální a nakonec zakotvil v České straně národně sociální.

47 KOSEK, J. Citadela nebo doupě; v zajetí ambivalence, s. 86.

48 Závěrečná řeč dr. Baxy. Dostupná zde: https://hruzovaanezka.wordpress.com/2007/12/30/vrazda-na-anezce -hruzove.

49 KOSEK, J. Citadela nebo doupě; v zajetí ambivalence, s. 86. 
roval „tolik nestoudnosti, nemyšlení, vášnivé ukvapenosti a $k$ tomu př́mo nelidskosti až ukrutnosti“, že se dal vysvětlit pouze „nervózní podrážděností a abnormálním stavem českého a rakouského života vỉbec". Jak už to v některých historicky významných kauzách bývá, na konkrétních lidských osudech v nich záleží méně než na dlouhodobých dopadech daných př́padů. Na osudu povaleče Hilsnera Masarykovi nijak zvlášt’ nesešlo, kvůli němu by do celé věci rozhodně nevstupoval. Byl však přesvědčen, že „,celý proces polenský a jeho antisemitské využivání je atentátem proti zdravému lidskému rozumu a lidskosti“.50

Jak sám vzpomíná, zprvu se o proces nezajímal. Obdržel však dopis svého bývalého žáka Sigmunda Münze z Vídně, který vyjadřoval údiv nad antisemitským př́istupem českého tisku k polenskému př́ípadu a zajímal se o Masarykův názor. Masaryk na jeho dopis odpověděl a v závěru svého listu připsal doušku, že adresát může s dopisem dále nakládat dle svého uvážení. Münz se pak rozhodl Masarykův dopis postoupit významnému vídeňskému listu Neue Freie Presse, který se jej rozhodl publikovat. ${ }^{51}$ „Tím jsem se, “ vzpomíná Masaryk, „dostal do té mely. Videňští antisemité poštvali český nacionální a klerikální tisk, začali tlouci do mne - nu, musel jsem se bránit; když už jsem řekl A, řekl jsem i B a C. Musel jsem k tomu študovat kriminalistiku i fyziologii; o tom všem jsem tenkrát dal veřejnosti podrobnějši zprávu. Zajel jsem i do Polné, abych prohlédl místo zločinu a jeho okolí. Pak řekli, že jsem za to placen od Židü. "52

Výsledky svého soukromého šetření sepsal Masaryk do brožury Nutnost revidovati proces polenský. „Započal-li jsem svou práci v této afére, nečinil jsem tak z filosemitismu, nýbrž z procítěné lidskosti, ale také proto, že hanba rituální pověry padá na český národ." Protimasarykovská kampaň musela dosahovat mimořádné intenzity, nebot' i světovou válkou zocelený Masaryk ve svých vzpomínkách přiznává, že „tu kampan̆ dost ucítil, ne tak kvůli sobě, ale bylo mně stydno za tu úroveň... boje pro své vystoupení v procesu proti Hilsnerovi... byly hrubé, přimo barbarské. Tenkrát nejen studentstvo, nýbrž i universita se podrobila nekulturnímu tlaku antisemitské ulice... Vidím ty ustrašené tváre různých svých známých; vzpomínám, jak se mně vyhýbali... Prodělal jsem boje různé, ale boj proti antisemitismu stál mě nejvíce námahy a času, nejvíce nejen klidného, rozumného napětí, nýbrž $i$ citového vzrušení... "53 Jak ovšem bylo Masarykovým dobrým zvykem, spory, do kterých se pustil, nevzdával. A zpravidla nakonec i vyhrával, jakkoli mnohdy až po dlouhých letech. ${ }^{54}$

O hluboké zakořeněnosti antisemitismu v české společnosti svědčí i Masarykovo osobní vyznání ze svého vztahu k židům: „Židi̊, těch jsem se bál; věřil jsem, že potře-

50 MASARYK, T. G. Nutnost revidovati proces polenský. Praha: Čas, 1899.

51 KOVTUN, J. Tajuplná vražda: Př́pad Leopolda Hilsnera, s. 236-237.

52 ČAPEK, K. Hovory s T. G. Masarykem. Praha: Československý spisovatel, 1990, citováno dle https:// web2.mlp.cz/koweb/00/03/34/75/88/hovory_s_t_g_masarykem.pdf, s. 92-93.

53 Tamtéž, s. 93 a OPAT, J. Masaryk - kritik rasismu, s. 42.

54 V časopise vídeňských Čechů s v daném kontextu ironickým názvem Pravda např. psali: ,Masaryk od jisté české veřejnosti jest již delši dobu uctíván jako, největši Čech'. Pravíme: od jisté veřejnosti. Tou je ,česká ‘ obec židovská. Židé, kteři pred tisíciletími tančili na poušti kolem zlatého telete, toči se nyní v Čechách kolem prof. Masaryka. Je to vskutku rituelní tanec židovský kolem obhájce židovského vraha z Polné a odpůrce rituelní vraždy židovské. Diviti se jen možno, že, největši Čech 'nechá se uctívati protičeským živlem a že z koure palestýnského kadidla nedělá se jeho české duši nanic." Citováno dle KOSEK, J., Citadela nebo doupě; v zajetí ambivalence, s. 82. 
buji křestanské krve, a proto jsem si raději zašel o pár ulic, než abych šel podle jejich stavení; jejich děti si chtěly se mnou hrát, protože jsem trochu uměl německy, ale já ne. Teprve později jsem se se Židy jaktak smíril... méli školní výlet do Pálavských kopcü. Když jsme po obědě v hospodě skotačili a dělali hlouposti, ztratil se nám spolužák Žid na dvi̊r. Já ze zvědavosti za ním, on se postavil za rozevřené kř́dlo vrat a tam se tvář ke zdi ukláněl a modlil. Tu jsem se nějak zastyděl, že se Žid modlí, zatímco my si hrajem. To mi tak nešlo do hlavy, že se modli stejně vroucně jako my a že nezapomíná na modlitbu ani za hry... a vidite, po celý život jsem se snažil dávat pozor, abych nebyl k Židưm nespravedlivý; proto se ř́kalo, že s nimi držím. Kdyže jsem v sobě prekonal ten lidový antisemitism? Panáčku, citem snad nikdy, jen rozumem; vždyt’ vlastní matka mě udržovala v krevni pověre. " 55

Hilsneriáda představovala pro Masaryka jeden z nejtěžších bojů jeho kariéry. Na dlouhou dobu ho zaměstnala, hluboce jím otřásla a přivedla $\mathrm{k}$ vážným myšlenkám na emigraci. Zejména americký univerzitní svět nabízel tomuto již v té době světově proslulému profesoru úplně jiný druh kariéry než malé, nesebevědomé a zakomplexované země české. Skutečnost, že Masaryk své rodné české země neopustil a vytrvale bojoval proti národním mýtům, at již se týkaly rukopisů nebo rituální vraždy, dává nakonec celé hilsnerově aféře alespoň nějaký širší smysl. Ostatně, právě při bojích za nezávislost Československa, o kterou během první světové války skupina pod vedením Masaryka začala usilovat, přinesl teprve Masarykův boj za Hilsnera své ovoce. Židé měli vliv na světový tisk a odvděčovali se Masarykovi, kterého znali z hilsnerovy aféry, tím, že psali o ,naši věci sympaticky nebo aspoň slušně. Politicky nám to hodně pomohlo“, vzpomíná budoucí prezident pomalu se rodícího státu. ${ }^{56}$

Právníci z hodin státovědy dobře vědí, že revoluční Národní shromáždění zvolilo Masaryka prezidentem nově vzniklého státu v jeho nepř́itomnosti aklamací. Patří už k ironii osudu, že když se v prosinci 1918 světoznámý univerzitní profesor a prezident vítězoslavně vracel domů, při př́ijezdu do Prahy ho uvítal také - Karel Baxa, budoucí první předseda československého ústavního soudu a hrdý nositel pražského primátorského řetězu, který nesundal po většinu doby Masarykova prezidentování. ${ }^{57}$

\section{ZÁVĚR}

Autoři zabývající se hilsneriádou často připomínají, že celá aféra vypukla př́značně na konci století, které samo sebe označovalo za racionální a vědecké a ve kterém minimálně vzdělanci překonali bludy minulosti. Hilsnerův př́pad, jako i ostatní procesy zabývající se nařčením z rituální vraždy ukazují, jak pod povrchem pokrokářské ideologie a nesporného technologického rozvoje přežívají nejprimitivnější pověry. Současně polenská aféra předznamenala i neblahé události století přicházejícího, které

55 ČAPEK, K. Hovory s T. G. Masarykem, s. 11-12.

56 Tamtéž, s. 93.

57 Dokument Hilsnerova aféra, Česká televize, 2006, dostupný na: http://www.ceskatelevize.cz/ivysilani /10114392043-hilsnerova-afera/206542152000001/titulky, 29. minuta. 
co do počtu obětí a spáchaných nespravedlností násobně převýšilo příkoří, která židé zažili ve století 19. Zygmund Bauman připomíná, že holokaust 20. století by nebyl možný bez nárůstu moderní racionality a byrokracie, ideologie neustálého pokroku a technologického rozvoje, tj. presně těch charakteristik, na které bývá moderní doba nejvíce pyšná. ${ }^{8}$ Hilsnerova aféra přitom v nástupu novodobých nespravedlností 20. století sehrála svoji nezanedbatelnou roli: Adolf Hitler polenský proces znal a odkazoval na něj jako na zřetelný doklad židovské proradnosti. Selhání české inteligence, včetně té právnické, které jsme mohli na celé události pozorovat, pak bezprostředně předznamenává její selhání ve 30. letech století dvacátého. Když Karel Čapek ve třicátých letech píše, že „asistujeme jednomu z největších kulturních debaklů v dějinách světa“, kdy ,jeden celý národ, jedna celá říše přistoupila duchovně na víru v živočišnost, $v$ rasu a podobné nesmysly; prosím, celý národ i s univerzitními profesory, farárí, literáty, lékaři a právniky", neplatí to o jen hitlerovském Německu, ale do značné míry i o národně-obrozeneckých českých zemích. $\mathrm{V}$ obou př́padech „se nestalo nic menšího než nesmírná zrada vzdělanců a budí to hroznou představu o tom, čeho je inteligence schopna". ${ }^{59}$

Jak ukazuje v úvodu zmíněný Bartošův čin, hilsneriáda není ani po téměř 120 letech zapomenutou událostí, jakkoli bývá mnohdy neprávem zapomínána či vytěsňována. Tím spís je třeba ocenit kvalitně zpracovaný a historicky přesný film České televize Zločin v Polné, který starou událost i její právní a společenské souvislosti věrohodně vykresluje. Je jedině dobře, že film získal pozitivní ohlasy diváků i kritiků. Snad nikoli jen za to, že pobavil, ale i poučil. Nebot' zejména v čase debat o migrační krizi je dobré si připomínat, kam mohou vést nereflektované, nezkrocené a kolektivně sdílené předsudky. Pro právníky pak Hilsnerův př́ípad přináší poučení stran toho, jak důležité jsou jednotlivé záruky spravedlivého soudního řízení a oddělení orgánů exekutivy od institucí soudních, jak důležité je dokázat nepodlehnout veřejnému mínění, jak důležitou roli ve společnosti právníci zastávají a jak významně jejich profesní selhání může ovlivnit aktuální nálady ve společnosti i její dlouhodobější směřování.

Znepokojivě neuzavřeným zůstává Hilsnerův př́pad ještě z jednoho důvodu. I když Hilsner obdržel v roce 1918 milost, je jeho jméno dosud právně neočištěné, a to i přes vytrvalé úsilí Petra Vašíčka, českého lékaře žijícího ve Vídni, který o jeho rehabilitaci vytrvale bojuje s českými i rakouskými vrcholnými justičními orgány. Ministryně spravedlnosti ČR Vlasta Parkanová sice již v 1998 dala Vašičkovi zapravdu, že v trestním rízení vedeném proti Hilsnerovi došlo k porušení zákona, konstatovala však, že s ohledem na opravné prostředky dostupné $\mathrm{v}$ době řízení nejsou české soudy pravomocné vydat v této věci rozhodnutí, které by porušení zákona stvrzovalo. Doporučila mu obrátit se na rakouské orgány, nebot' ve věci rozhodoval kasační soud ve Vídni. ${ }^{60}$ Ani rakouská justice ovšem nápravu nezajistila, když na žádost dr. Vašičcka odpověděla, že již nemá

58 Srov. BAUMAN, Z. Modernita a holocaust. Praha: Sociologické nakladatelství, 2003.

59 ČAPEK, K. Zima 34. In: ČAPEK, K. O uměni a kultuře III. Praha: Československý spisovatel, 1986, citováno dle https://web2.mlp.cz/koweb/00/03/34/76/15/o_umeni_a_kulture_iii.pdf, s. 439.

${ }^{60}$ Dopis ministryně spravedlnosti JUDr. Vlasty Parkanové adresovaný MUDr. Petru Vašíčkovi ze dne 5. února 1998. Citováno dle Kolektiv autorů. Hilsnerova aféra a česká společnost 1899-1999. Praha: Židovské muzeum v Praze, 1999, s. 186. 
k dispozici příslušnou spisovou dokumentaci, která by byla pro přezkum kauzy nezbytná. ${ }^{61}$ Soukolí, do kterého byl shodou okolností před téměř 120 lety Hilsner zatažen, ho dosud nepustilo a nic nenasvědčuje tomu, že se to může změnit.

JUDr. Mgr. Michal Urban, Ph.D.

Právnická fakulta Univerzity Karlovy

urbanm@prf.cuni.cz

Mgr. Eliška Hronová

Ministerstvo spravedlnosti ČR

ehronova@msp.justice.cz

61 Dopis dr. Thomase Solého jménem rakouského Ministerstva spravedlnosti ze dne 26. června 1999. Citováno dle Kolektiv autorů. Hilsnerova aféra a česká společnost 1899-1999. Praha: Židovské muzeum v Praze, 1999, s. 210-211. Můžeme doplnit, že v roce 1927 opravdu došlo k požáru vídeňského Justičního paláce a poškozen či zničen mohl být i Hilsnerův spis. 